FULFILLING THE SACRED TRUST 



\section{FULFILLING THE SACRED TRUST}

THE UN CAMPAIGN FOR INTERNATIONAL ACCOUNTABILITY FOR DEPENDENT TERRITORIES IN THE ERA OF DECOLONIZATION

\section{MARY ANN HEISS}




\section{Copyright (C) 2020 by Cornell University}

All rights reserved. Except for brief quotations in a review, this book, or parts thereof, must not be reproduced in any form without permission in writing from the publisher. For information, address Cornell University Press, Sage House, 512 East State Street, Ithaca, New York 14850.

First published 2020 by Cornell University Press

Library of Congress Cataloging-in-Publication Data

Names: Heiss, Mary Ann, 1961- author.

Title: Fulfilling the sacred trust : the UN campaign for international accountability for dependent territories in the era of decolonization / Mary Ann Heiss.

Description: Ithaca [New York] : Cornell University Press, 2020. Includes bibliographical references and index.

Identifiers: LCCN 2020007239 (print) |

LCCN 2020007240 (ebook)

ISBN 9781501752704 (hardcover) |

ISBN 9781501752711 (ebook)

Subjects: LCSH: United Nations-History—20th century. Decolonization. | Non-self-governing territories. | Self-determination, National.

Classification: LCC JV151 .H45 2020 (print) |

LCC JV151 (ebook) | DDC 341.2/8-dc23

LC record available at https://1ccn.loc.gov/ 2020007239

LC ebook record available at https:// lccn.loc.gov 
For CEW 
